This article is licensed under the Creative Commons Attribution-NonCommercial 4.0 International License (CC BY-NC) (http://www.karger.com/Services/OpenAccessLicense). Usage and distribution for commercial purposes requires written permission.

\title{
An Alternative Approach to the Terminal Management of Ogilvie Syndrome
}

\author{
Daniel Galban Joshua J. Baiel \\ Trinity School of Medicine, Alpharetta, GA, USA
}

\section{Keywords}

Ogilvie syndrome $\cdot$ Pseudo-colonic obstructions $\cdot$ Tube cecostomies

\begin{abstract}
Ogilvie syndrome is defined as colonic pseudo-obstruction due to nonmechanical causes. Mortality of nearly $50 \%$ is associated with perforation of the distended, pseudo-obstructed colon. While conservative medical therapy has proven to be beneficial in a majority of cases, $>3 \%$ of patients have significant distention or perforation of the colon that warrants surgical resection. The case of a 48-year-old male with progressive abdominal discomfort and distention 12 days following knee replacement surgery is presented. He was subsequently diagnosed with colonic pseudo-obstruction and definitively treated with subtotal colectomy and colostomy. We propose that a more conservative approach to treatment of colonic pseudoobstruction may prevent the need for colostomy, significantly improving quality of life.
\end{abstract}




\section{Case Reports in Gastroenterology}

Case Rep Gastroenterol 2017;11:352-358

(c) 2017 The Author(s). Published by S. Karger AG, Basel www.karger.com/crg

Galban and Baiel: An Alternative Approach to the Terminal Management of Ogilvie Syndrome

\section{Introduction}

Ogilvie syndrome was first described by Sir Heneage Ogilvie in 1948. His original case report presented 2 patients with colonic obstruction without any diagnosed colonic pathology. Upon exploratory laparotomy, these patients were found to have areas of carcinoma unrelated to the colon [1]. It was hypothesized that the carcinoma was responsible for disrupting the balance between the parasympathetic and sympathetic nervous systems, leading to colonic pseudo-obstruction. Maloney and Vargas [2] showed success following treatment with neostigmine, providing further evidence for pseudo-obstruction. Ogilvie syndrome has been expanded to include other causes of pseudo-obstruction, as found in postoperative patients or those with metabolic anomalies [3].

\section{Case Report}

We present the case of a 48-year-old male with a past medical history of diabetes mellitus, hypertension, hypercholesterolemia, and intellectual disability who arrived at the ER from a nursing home with abdominal distention 12 days following right total knee arthroplasty. He described progressive distention without pain, which had been progressing since the surgery. He reported having daily bowel movements during this period. The patient denied nausea, vomiting, fever, or chills.

The review of systems was unremarkable. The clinical exam showed vital signs that were within normal limits. Physical examination revealed gross distention of the abdomen, which was otherwise soft and nontender without rebound, guarding, or rigidity. Normal bowel sounds were present. Digital exam revealed soft brown stool in the rectal vault, and no masses or significant tenderness was appreciated. The remainder of the physical exam was essentially unremarkable. Laboratory results were also unremarkable (Table 1). Roentography (Fig. 1) and CT (Fig. 2) of the abdomen revealed massive colonic dilatation from cecum to rectum without any observable masses or narrowings.

The patient was initially managed with trials of enemas at the nursing home for 2 days without improvement. Patient was kept NPO for that duration until it was decided to take the patient to the ER. In the ER, a CT of the abdomen was done, which showed markedly distended colon with fluid and gas extending to the rectum. The next day, the patient underwent flexible sigmoidoscopy. The patients' distention markedly improved, albeit for a finite amount of time. Eventually, the distention came back full force which led to the diagnosis of Ogilvie syndrome. That same day, measures to replete potassium were made. Six days later, he was given a trial of $2 \mathrm{mg}$ neostigmine. He had 2 bowel movements following neostigmine infusion; however, the colonic distention did not resolve. A second trial of neostigmine was given the next day but with similar results, and the decision for surgical decompression and subtotal colectomy with colostomy was subsequently made with failure of conservative management. Intraoperatively the following day, the cecum was found to be $8 \mathrm{~cm}$ in diameter and the rectum was $15 \mathrm{~cm}$ in diameter. The total amount of resected colon was $160 \mathrm{~cm}$. His postsurgical hospital course was uneventful. His diet was advanced successfully on postoperative day 3 with return of bowel function occurring on postoperative day 4 . He had no further complications on subsequent office visits. 


\section{Case Reports in Gastroenterology}

Case Rep Gastroenterol 2017;11:352-358

(c) 2017 The Author(s). Published by S. Karger AG, Basel www.karger.com/crg

Galban and Baiel: An Alternative Approach to the Terminal Management of Ogilvie Syndrome

\section{Discussion}

Conservative treatment has proven to be efficacious in the management of Ogilvie syndrome [4]. A study by Vanek and Al-Salti [5] showed a drastic decrease in mortality when colonic decompression was performed early in management especially with cecal diameters $>12 \mathrm{~cm}$. As a greater understanding of the underlying mechanism was achieved, neostigmine emerged as an efficacious treatment for acute colonic pseudo-obstruction unresponsive to conservative management [6]. In 2 uncontrolled studies, intravenous neostigmine was effective in $80 \%$ of patients $[7,8]$. Due to the risks associated with colonic distension and perforation, more invasive management is sought with failure after 2 trials of neostigmine or if neostigmine is contraindicated [2].

A review of 50 cases treated with colonoscopic decompression determined that it was $88 \%$ successful. The placement of a temporary decompression tube guided by the scope increased the efficacy [9]. In cases unresponsive to therapy, tube cecostomy is the preferred intervention. This is advantageous as it allows decompression of the large bowel and can be performed outside of the operating room in severely ill patients. Additionally, this method has proven efficacious in most reported cases $[10,11]$. The most aggressive treatment, including the definitive treatment in our patient, involves subtotal or total colectomy with ileostomy.

While initially a promising treatment, percutaneous tube cecostomy quickly went under the scrutiny of critics. Wound infection, cecal fistula, and intraperitoneal leakage were commonly reported complications following placement [12]. A 1995 review of tube cecostomies used for the treatment of mechanical and pseudo-obstruction of the colon showed high complication rates. In a review of 67 patients, $45 \%$ had minor complications following placement of a tube cecostomy, including infection, occlusion, and premature dislodgment [11]. However, reoperation was not required in any of these patients, demonstrating both the success of this method and the lack of severe complications. A 2015 study involving cancer patients with large bowel obstruction further supported the use of tube cecostomy. No cases of colonic perforation were reported, and catheter removal was possible in 6 of 9 patients with pseudo-obstruction. Only 1 case out of 27 resulted in severe complications, and those were successfully managed with replacement of the cecostomy tube and antibiotics [13].

Chudzinski et al. [14] suggested surgical resection with colostomy or percutaneous tube cecostomy as treatment following failure of medical management in the resolution of colonic pseudo-obstruction. The decision regarding total versus subtotal colectomy is made based on the extent of the dilation. This more invasive option is associated with increased morbidity and mortality, especially when the reversal is taken into consideration. According to a 2005 retrospective cohort study, reversal and closure of the colostomy stoma is associated with a $20 \%$ complication rate and $3 \%$ mortality, with age being the only significant risk factor. Complications included anastomotic leaks and infections [15].

Ogilvie syndrome, although better understood today than when Ogilvie first described the disease, is still shrouded in mystery. Imbalance between parasympathetic and sympathetic stimulation is at the root of the issue; however, the specific mechanism of action has yet to be revealed. The current management for colonic pseudo-obstruction without peritoneal signs and colonic diameter $<12 \mathrm{~cm}$ is 2 trials of neostigmine followed by endoscopic decompression and finally colostomy with failure and recurrence. However, colostomy is 
fraught with complications and significantly reduces a patient's quality of life. Percutaneous tube cecostomy was once considered the standard of care with success rates up to $95 \%$. Complications related to the management of the stoma, infection, and dislodgement of the tube led to its loss in popularity. Recent studies have suggested that current methods have led to a reduction in serious complications without sacrificing the success of the treatment modality. It is our opinion that tube cecostomy should be revisited as an alternative to colostomy in the resolution of pseudo-obstruction of the colon refractory to a more conservative medical management.

\section{Statement of Ethics}

The patient's guardian provided informed consent for the patient's participation as the patient has a mental disorder.

\section{Disclosure Statement}

The authors have nothing to disclose. This case series was funded by the authors.

\section{References}

Ogilvie H: Large-intestine colic due to sympathetic deprivation. BMJ 1948;2:671.

Maloney N, Vargas HD: Acute intestinal pseudo-obstruction (Ogilvie's syndrome). Clin Colon Rectal Surg 2005;18:96-101.

3 Nanni C, Garbini A, Luchetti P, Nanni G, Ronconi P, Castagneto M: Ogilvie’s syndrome (acute colonic pseudo-obstruction): review of the literature (October 1948 to March 1980) and report of four additional cases. Dis Colon Rectum 1982;25:157.

-4 Sloyer AF, Panella VS, Demas BE, et al: Ogilvie's syndrome. Successful management without colonoscopy. Dig Dis Sci 1988;33:1391-1396.

-5 Vanek VW, Al-Salti M: Acute pseudo-obstruction of the colon (Ogilvie's syndrome). An analysis of 400 cases. Dis Colon Rectum 1986;29:203-210.

-6 Ponec RJ, Saunders MD, Kimmey MB: Neostigmine for the treatment of acute colonic pseudoobstruction. N Engl J Med 1999;341:137-141.

7 Stephenson BM, Morgan AR, Salaman JR, Wheeler MH: Ogilvie's syndrome: a new approach to an old problem. Dis Colon Rectum 1995;38:424-427.

-8 Turégano-Fuentes F, Muñoz-Jiménez F, Del Valle-Hernández E, et al: Early resolution of Ogilvie's syndrome with intravenous neostigmine: a simple, effective treatment. Dis Colon Rectum 1997;40:1353-1357.

-9 Geller A, Petersen BT, Gostout CJ: Endoscopic decompression for acute colonic pseudo-obstruction. Gastrointest Endosc 1996;44:144-150.

10 Caves P, Crockard H: Pseudo-obstruction of the large bowel. BMJ 1970;2:583-586.

11 Benacci JC, Wolff BG: Cecostomy. Therapeutic indications and results. Dis Colon Rectum 1995;38:530534.

12 Clark DD, Hubay CA: Tube cecostomy: an evaluation of 161 cases. Ann Surg 1972;175:55-61.

13 Tewari SO, Getrajdman GI, Petre EN, et al: Safety and efficacy of percutaneous cecostomy/colostomy for treatment of large bowel obstruction in adults with cancer. J Vasc Interv Radiol 2015;26:182-188. 


\section{Case Reports in \\ Gastroenterology}

\begin{tabular}{l|l}
\hline Case Rep Gastroenterol 2017;11:352-358 \\
\hline DOI: 10.1159/000462963 & $\begin{array}{l}\text { @ 2017 The Author(s). Published by S. Karger AG, Basel } \\
\text { www.karger.com/crg }\end{array}$ \\
\hline
\end{tabular}

Galban and Baiel: An Alternative Approach to the Terminal Management of Ogilvie Syndrome

14 Chudzinski AP, Thompson EV, Ayscue JM: Acute colonic pseudoobstruction. Clin Colon Rectal Surg 2015;28:112-117.

15 Pokorny H, Herkner H, Jakesz R, Herbst F: Mortality and complications after stoma closure. Arch Surg 2005;140:956-960.

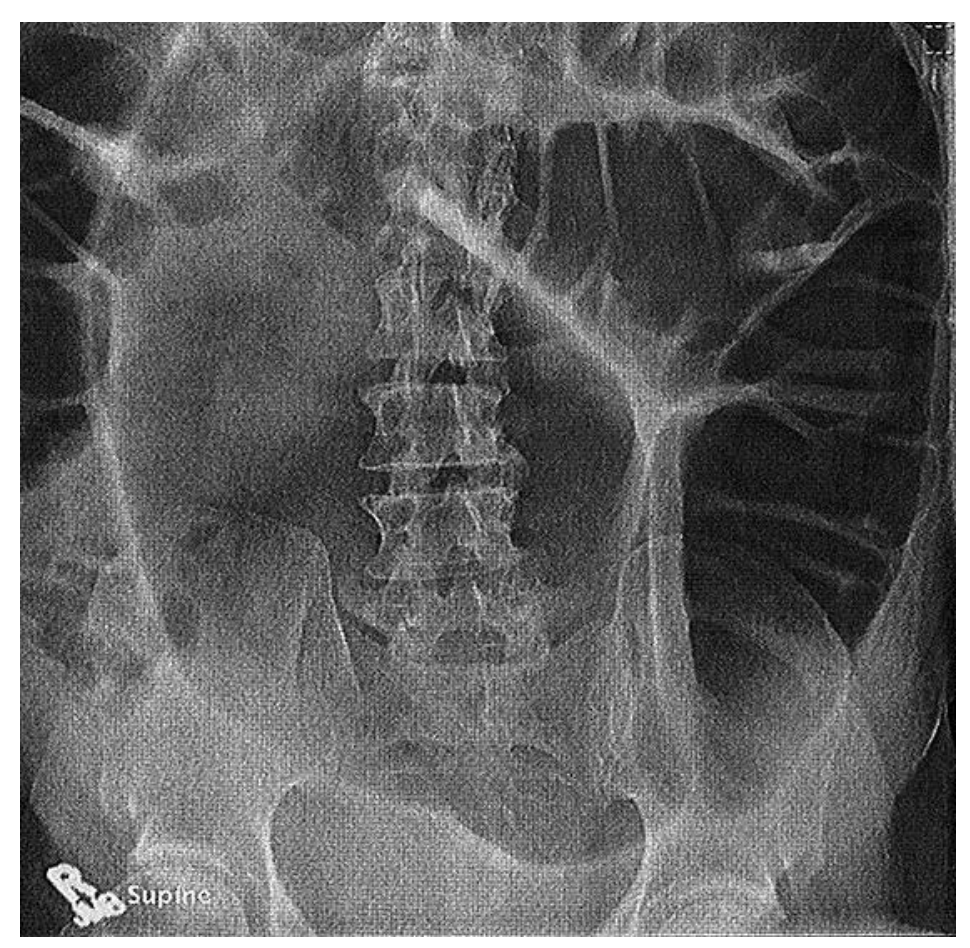

Fig. 1. Abdominal X-ray of the 48-year-old male with Ogilvie syndrome. 


\section{Case Reports in \\ Gastroenterology}

Case Rep Gastroenterol 2017;11:352-358

(C) 2017 The Author(s). Published by S. Karger AG, Basel www.karger.com/crg

Syndrome

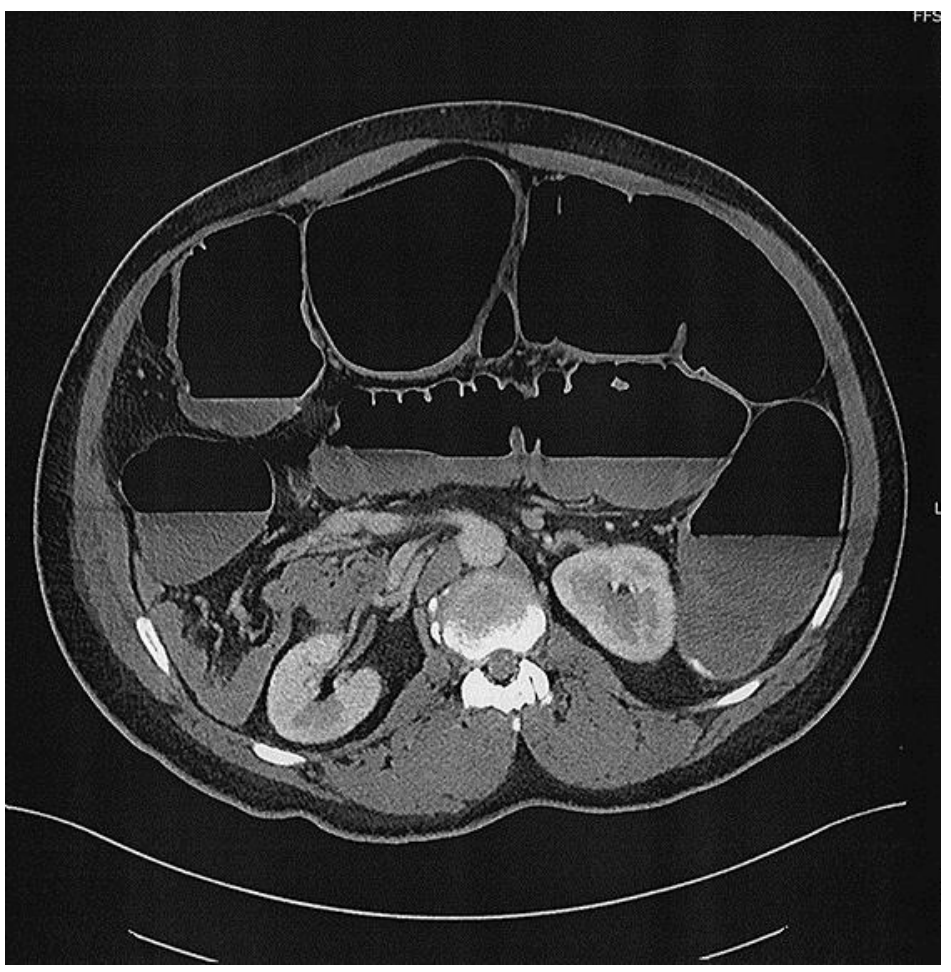

Fig. 2. Abdominal CT of the 48-year-old male with Ogilvie syndrome. 
Table 1. Laboratory results were essentially unremarkable

Glucose, $\mathrm{mg} / \mathrm{dL} \quad 104$

BUN, $\mathrm{mg} / \mathrm{dL} \quad 21$

Creatinine, $\mathrm{mg} / \mathrm{dL} \quad 0.8$

Sodium, $\mathrm{mmol} / \mathrm{L}$

Potassium, $\mathrm{mmol} / \mathrm{L}$

Chloride, $\mathrm{mmol} / \mathrm{L}$

$\mathrm{CO}_{2}, \mathrm{mmol} / \mathrm{L} \quad 27$

Anion Gap 6

Calcium, mg/dL $\quad 8.7$

Total protein, $\mathrm{g} / \mathrm{dL} \quad 6.7$

Albumin, g/dL $\quad 3.5$

Bilirubin total, $\mathrm{mg} / \mathrm{dL} \quad 0.9$

ALK phosphatase, $\mu / \mathrm{L} \quad 66$

AST, $\mu / \mathrm{L} \quad 16$

ALT, $\mu / \mathrm{L}$

$\mathrm{WBC}, \mathrm{k} / \mu \mathrm{L} \quad 3.9$

$\mathrm{RBC}, \mathrm{m} / \mu \mathrm{L} \quad 2.69$

Hemoglobin, g/dL $\quad 8.3$

Hematocrit 25.4

MCV 94

$\begin{array}{ll}\mathrm{MCH} & 30.9\end{array}$

MCHC $\quad 32.7$

Platelets, k/ $\mu \mathrm{L}$

RDW 15 